\title{
KEDEWASAAN BERAGAMA PADA ANAK USIA DASAR
}

\author{
Mar'atus Sholihah \\ Dosen PGMI IAI Al-Falah Assunniyyah Kencong-Jember \\ marmarapgmi@inaifas.ac.id
}

\begin{abstract}
Mature religion on children who are in elementary or primary phase plays an important rule for their psychology development. This paper found out in theory that children have the ability to recognize what is called "religion" in their heart through their mind by having imagination and thinking logically. The needs of having religion for children are constracted internally by themselves and externally by their environment, family and culture. Children develop their religion maturity by three stages based on their age. It is started from age 0-12 year old which explains different development they have. Those stage of developments are related with their ability to be critical and with three kind of intellengences (IQ-SQ-EQ).
\end{abstract}

Keywords: Mature Religion, Children, Development

\section{PENDAHULUAN}

Keagamaan yang matang dalam diri seseorang banyak hal yang mempengaruhinya serta banyak faktor yang mendorongnya. Seseorang yang keagamaannya telah matang mempunyai kriteria-kriteria tertentu. Kematangan beragama juga sangat berkaitan erat dengan perkembangan dan kematangan kepribadian. Manusia pada dasarnya mengalami dua macam perkembangan, yaitu perkembangan jasmani dan perkembangan rohani. Perkembangan jasmani di ukur berdasarkan umur kronologis, puncak perkembangan jasmani yang dicapai oleh seseorang disebut kedewasaan. Perkembangan rohani diukur berdasarkan tingkat kemampuan (abilitas). Pencapaian tingkat abilitas tertentu bagi perkembangan rohani disebut dengan istilah kematangan (maturity).

Kita sering menjumpai bahwa mereka yang taat beragama itu dilatarbelakangi oleh berbagai pengalaman agama serta tipe kepribadian masingmasing. Kondisi seperti ini akan sangat mempengaruhi keagamaan seseorang, terutama dalam memahami dan melaksanakan sesuai dengan keyakinannya, begitu pun yang terjadi pada kematangan beragama pada anak-anak di usia dasar.

FaLASIFA, Vol. 9 Nomor 1 Maret 2018 | 97 
Mar'atus Sholihah

\section{PEMBAHASAN}

\section{Pengertian Mature Religion (Kedewasaan Beragama)}

Pengertian agama berdasarkan asal kata, yaitu Al-Din, religi (velegere, religare) dan agama. Al-din (semit) berarti undang-undang atau hukum. Kemudian alam bahasa arab, kata ini mengandung arti menguasai, mendudukkan, patuh, utang, alasan, kebiasaan. Kata religi (latin) atau relegere berarti mengumpulkan dan membaca, kemudian religare berarti mengikat. Kata agama terdiri dari $(\mathrm{a}=$ tidak; gama $=$ pergi $)$, sehingga mengandung arti tidak pergi, tetap di tempat atau diwarisi turun-temurun.

Bertitik tolak dari pengertian di atas, menurut Harun Nasution, agama adalah:

1. Pengakuan terhadap adanya hubungan manusia dengan kekuatan gaib yang harus dipatuhi.

2. Pengakuan terhadap adanya kekuatan gaib yang menguasai manusia.

3. Mengikat daripada suatu bentuk hidup yang mengandung pengakuan pada suatu sumber yang berada di luar diri manusia dan yang mempengaruhi perbuatan-perbuatan manusia.

4. Kepercayaan pada suatu kekurangan gaib yang menimbulkan cara hidup tertentu.

5. Suatu sistem tingkah laku (code of conduct) yang berasal dari sesuatu kekuatan gaib.

6. Pengakuan terhadap adanya kewajiban-kewajiban yang diyakini bersumber pada suatu kekuatan gaib.

7. Pemujaan terhadap kekuatan gaib yang timbul dari perasaan lemah dan perasaan takut terhadap kekuatan misterius yang terdapat dalam alam sekitar manusia.

8. Ajaran-ajaran yang diwahyukan tuhan kepada manusia melalui seorang rasul. ${ }^{1}$

Durkheim mengatakan bahwa agama merupakan alam gaib yang tidak dapat diketahui dan tak dapat dipikirkan oleh akal dan pikiran manusia sendiri. Pengertian agama secara tegas yaitu suatu bagian daripada pengetahuan yang tidak dapat dicapai oleh ilmu pengetahuan biasa dan juga tidak dapat diperoleh dengan tenaga pikiran saja. Pendapat lain dari Syekh Mustafa Ar Roziq, agama yaitu peraturan-peraturan yang terdiri dari kepercayaan-kepercayaan dan pekerjaanpekerjaan yang berat dengan keadaan-keadaan yang suci, artinya yang membedakan mana yang halal dan mana yang terlarang (haram) yang dapat hlm.,12-13.

${ }^{1}$ H. Jalaluddin, Psikologi Agama (Jakarta: PT RajaGrapindo Persada, 2012),

98 | FalASIFA, Vol. 9 Nomor 1 Maret 2018 
membawa atau mendorong umat yang menganutnya untuk menjadi suatu umat yang mempunyai kesatuan rohani yang kuat. Prof. Dr. Syekh Mahmud Syaltout memandang agama dalam arti syariat sebagai berikut: segala sesuatu yang telah ditentukan oleh Allah terhadap hambanya yang meliputi hubunganya dengan tuhan, hubungan antar sesama muslim, hubungan antar sesama manusia, hubungan dengan makhluk hidup dan hubungannya dengan alam sekitar. ${ }^{2}$

Kematangan beragama diartikan dengan beberapa istilah oleh banyak orang. Pendapat-pendapat yang muncul mengatakan bahwa kematangan beragama ada yang menyebutkan jika seseorang itu telah mampu mengendalikan nafsunya, mengendalikan dirinya dari perbuatan yang tidak dikehendaki oleh agama yang dianutnya. Pendapat lain mengatakan bahwa orang yang telah matang agamanya adalah orang yang mampu mengelola hidupnya dengan baik dan stabil.

Kemampuan seseorang untuk mengenali atau memahami nilai agama yang terletak pada nilai-nilai luhurnya serta menjadikan nilai-nilai dalam bersikap dan bertingkah laku merupakan ciri kematangan beragama. Kematangan beragama terlihat dari ketika seseorang mampu mamahami, menghayati serta mengaplikasikan nilai-nilai luhur agama yang dianutnya dalam kehidupan seharihari. ${ }^{3}$ Ia menganut agama tersebut karena menurut keyakinan mereka bahwa agama tersebutlah merupakan agama yang terbaik, maka dari itulah mereka berusaha untuk menjadi penganut agama yang baik. Seseorang dalam menganut agama karena dilatar belakangi oleh berbagai pengalaman agama serta kepribadian masing-masing, maka hal ini akan sangat mempengaruhi kematangan agama dalam diri seseorang. Konsep-konsep kematangan beragama menurut beberapa tokoh dijelaskan dibawah ini:

\section{Walter Houton Clark}

Clark dalam diskusi tentang kematangan beragama ini mendefinisikan agama sebagai "pengalaman keberjumpaan batin seseorang dengan Tuban yang pengaruhnya dibuktikan dalam perilaku nyata hidup seseorang". Penjelasan dari pengertian agama Clark ini adalah ketika seseorang secara aktif berusaha melakukan harmonisasi atau penyelarasan hidupnya dengan Tuhan”, itulah kematangan beragama yang didefiniskan Clark. Kematangan beragama dalam konsepnya yang ideal meniscayakan suatu kesadaran ketuhanan (God awareness) atau realitas kosmis lain, yang tercermin dalam pengalaman "ke

${ }^{2}$ M. Hafi Anshari, Dasar-dasar Ilmu Jiwa Agama (Surabaya: Usaha Nasional, 1991), hlm. 105-107.

${ }^{3}$ Jalaludin, Psikologi Agama: Memahami Perilaku Keagamaan Dengan Mengaplikasikan Prinsip-Prinsip Psikologi (Jakarta: PT Raja Grafindo Persada, 2010), hlm. 125. 
Mar'atus Sholihah

dalam" dan terekspresi "ke luar". Ciri-ciri dari keberagamaan yang matang menurut Clark adalah sebagai berikut:

a. Pertama, lebih kritis, kreatif dan otonom dalam beragama.

b. Kedua, keberagamaan matang memperluas perhatiannya terhadap hal-hal di luar dirinya.

c. Ketiga, keagamaan matang tidak puas semata-mata dengan rutinitas ritual dan verbalisasinya.

\section{Gordon Allport}

Psikolog terkenal Allport memberikan ciri-ciri kematangan beragama beberapa kriteria berikut, yaitu: Pertama, berpengetahuan luas dan rendah hati (well-differentiated and self critical). Orang beragama dengan ciri ini mengimani dan memiliki kesetiaan yang kuat terhadap agamanya, namun juga ia mengakui kemungkinan "kekurangan" untuk diperbaiki sehingga mau belajar kepada siapa pun termasuk kepada pemeluk agama lain. Orang yang beragama matang juga bisa menerima kritik tetapi memiliki fondasi kuat tentang agama dan institusi agamanya. Agama matang pada intinya menggunakan nalar sebagai faktor integral dalam keberagamaannya yang berfungsi secara dinamis dalam beragama.

Kedua, menjadikan agama sebagai kekuatan motivasi (motivational force). Orang yang matang dalam beragama menjadikan agama sebagai tujuan dan kekuatan yang selalu dicari untuk mengatasi setiap masalah yang selanjutnya membawa pada transformasi diri. Ketiga, memiliki moralitas yang konsisten (moral consistency). Orang yang beragama matang memiliki perilaku yang sejalan dengan nilai-nilai moral secara konsisten dalam perilaku nyata seharihari.

Keempat, pandangan hidup yang komprehensif (comprehensiveness), yang intinya adalah toleransi. Orang yang beragama matang memiliki keyakinan kuat akan agamanya tetapi juga mengharuskan dirinya untuk hidup berdampingan secara damai dan harmonis dengan orang lain yang berbeda dengan dirinya. Konflik kekerasan tentu bukan bagian dari kehidupannya karena toleransi merupakan visi hidupnya.

Kelima, pandangan hidup yang integral (integral). Kriteria ini melibatkan refleksi dan harmoni, dan hidup yang berguna. Orang yang beragama dengan matang, sejalan dengan prinsip keempat sebelumnya, memiliki visi hidup yang harmoni atau damai. Ia juga mengorientasikan hidupnya agar dapat berguna bagi orang lainnya.

Keenam, heuristic. Kriteria ini bermaksud bahwa orang yang beragama matang selalu mencari kebenaran dan memahami pencapaian sementara

100 | FaLASIFA, Vol. 9 Nomor 1 Maret 2018 
tentang keyakinannya itu, yang menjadikannya seorang "pencari" selamanya. Orang yang beragama matang memiliki kerendahan hati dan keterbukaan atas pandangan-pandangan keagamaan baru dan menjadikan perkembangan atau dinamika keagamaan sebagai sebuah pencarian asli.

Bagi Allport orang yang beragama matang memiliki dimensi akademisnya, sehingga kriterianya tentang kematangan beragama lebih disukai oleh kalangan akademisi. Pandangan Allport, untuk menjadi orang yang matang dalam beragama tidaklah sulit karena siapa pun bisa mencapai tingkat keberagamaan puncak ini.

\section{William James}

William James dianggap sebagai bapak psikologi agama. Bukunya yang terkenal The Varieties of Religious Experience merupakan pembahasan agama yang paling mendalam dan komprehensif. James berpendapat bahwa agama memiliki peran sentral dalam menentukan perilaku manusia. Dorongan beragama pada manusia menurut James paling tidak sama menariknya dengan dorongan-dorongan lainnya, oleh karena itu, agama patut mendapat perhatian dalam setiap pembahasan dan penelitian sosial yang lebih luas. James memberikan kriteria orang yang beragama matang sebagai berikut;

Pertama, sensibilitas akan eksistensi Tuhan, maksudnya adalah bahwa orang yang beragama matang selalu tersambung hati dan pikirannya dengan Tuhan. Perilaku orang yang beragama matang akan melahirkan kedamaian, ketenangan batin yang mendalam dan terhindar dari keburukan-keburukan hidup.

Kedua, kesinambungan dengan Tuhan dan penyerahan diri pada-Nya. Poin kedua ini merupakan konsekwensi dari yang pertama, di mana orang beragama matang secara sadar dan tanpa paksaan menyesuaikan hidupnya dengan kehendak Tuhan, yakni kebajikan karena Tuhan adalah Maha Baik. Orang yang beragama matang terbebas dari ego yang selalu membisikkan orang pada kejahatan-kejahatan, baik secara intra maupun interpersonal.

Ketiga, penyerahan diri sebagaimana dalam poin kedua melahirkan rasa bahagia dan kebebasan yang membahagiakan. James menandai sikap beragama sebagai kepercayaan akan adanya ketertiban tak terlihat dan keinginan untuk hidup serasi dengan ketertiban itu. Hubungan manusia dengan realitas tak terlihat, agama, melahirkan efek kehidupan secara individual. Ia akan mengaktifkan energi spiritual dan menggerakkan karya spiritual. Orang yang beragama matang memiliki gairah hidup, dan memberikan makna dan kemuliaan baru pada hal-hal yang lazimnya dianggap biasa-biasa saja. James karenanya melihat agama sebagai sumber kebahagiaan,

Falasifa, Vol. 9 Nomor 1 Maret 2018 | 101 


\section{Mar'atus Sholihah}

sehingga orang yang beragama matang menjalani kehidupannya dengan penuh kebahagiaan.

Keempat, orang yang beragama matang mengalami perubahan dari emosi menjadi cinta dan harmoni. Orang yang beragama matang mencapai perasaaan tenteram dan damai, di mana cinta mendasari seluruh hubungan interpersonalnya. Orang beragama matang bebas dari rasa benci, prejudice, permusuhan, dan lain-lain, tetapi cinta dan harmoni merupakan dasar bagi kehidupan sosial atau interpersonalnya. James berpandangan seorang rahib adalah tipe kehidupan ideal dari orang yang beragama matang ini sehingga nampaknya tidak semua orang dapat mencapai puncak keberagamaan matang ini. Seorang Sufi, Bikkhu dan Bikkhuni, Romo, dan yang sejenis masuk ke dalam tipe orang yang beragama matang menurut James ini.

\section{Wiemans}

Bukunya berujudul Normative Psychology of Religion Henry Nelson Wieman dan Regina Westcott Wieman menguraikan kriteria agama matang sebagai berikut:

Pertama, hidup yang bermanfaat secara kemanusiaan.

Kedua, loyalitas yang sempurna.

Ketiga, efisien dalam mencapai tujuan.

Keempat, hidup berdasarkan dan sensitif dalam memandang nilai.

Keempat, loyalitas yang terus tumbuh, dan

Keenam, loyalitas sosial yang efektif.

Inti dari ciri orang yang beragama matang menurut Wiemans adalah penekanannya pada kehidupan sosial yang diringkas dengan kesalehan sosial. Orang yang beragama matang mengimplementasikan kebagamaannya dari kebaikan sosial atau kesalehan sosial tadi. ${ }^{4}$

\section{Fungsi Agama}

\section{Fungsi agama dalam kehidupan individu}

a. Agama sebagai sumber nilai dalam menjaga kesusilaan

Ajaran dalam agama memiliki nilai-nilai bagi kehidupan manusia. Nilainilai inilah yang dijadikan sebagai acuan dan sekaligus sebagai petunjuk bagi manusia. Firman Allah yang artinya "kitab (Al-Qur'an) tidak ada keraguan padanya, petunjuk bagi mereka yang bertaqwa”. (Q.S. AlBaqarah: 2)

\footnotetext{
${ }^{4}$ Roni Ismail, Konsep Toleransi Dalam Psikologi Agama (Jurnal Religi, Vol. VIII,
} No. 1, Januari 2012), hlm. 3-6.

102 | FaLASIFA, Vol. 9 Nomor 1 Maret 2018 
Agama menjadi kerangka acuan dalam berfikir, bersikap, dan berperilaku agar sejalan dengan keyakinan yang dianutnya. McQuire memposisikan sistem nilai yang berdasarkan agama dapat memberi pedoman bagi individu dan masyarakat. Sistem nilai tersebut dalam bentuk keabsahan dan pembenaran dalam kehidupan individu dan masyarakat.

Individu yang tumbuh menjadi dewasa selalu memerlukan suatu sistem nilai sebagai tuntutan umum untuk mengarahkan aktivitas dalam masyarakat yang berfungsi sebagai tujuan akhir pengembangan kepribadiannya.

b. Agama sebagai sarana untuk mengatasi frustasi

Manusia mempunyai kebutuhan dalam kehidupan ini, mulai dari kebutuhan fisik seperti; makanan, ketenteraman, istrirahat, dan seksual, sampai kebutuhan psikis seperti; keamanan batin, ketenteraman batin, persahabatan, penghargaan, dan kasih sayang. Pengamatan psikologis menunjukkan bahwa keadaan frustasi itu dapat menimbulkan tingkah laku keagamaan. Orang yang mengalami frustasi tidak jarang bertingkah laku religius atau keagamaan untuk mengatasi frustasinya.

c. Agama sebagai sarana untuk mengatasi ketakutan

Ketakutan yang dimaksud dalam kaitannya dengan agama adalah bahwa agama dianut sebagai sarana untuk mengatasinya, fokusnya pada ketakutan yang tidak ada objek. Kita sering menemukan ketika seseorang medapatkan musibah maka ibadahnya semakin meningkat karena meminta kepada Allah SWT supaya masalah yang dihadapinya tetap selesai. Fungsi agama adalah untuk menemukan jalan keluar atau ketenangan dalam menghadapi masalah tersebut.

\section{d. Agama sebagai sarana untuk memuaskan keingintahuan}

Agama mampu memberi jawaban atas kesadaran intelektual kognitif, sejauh kesukaran itu diresapi oleh keinginan eksistensial dan psikologi, yaitu oleh keinginan dan kebutuhan manusia akan orientasi dalam kehidupan, agar dapat menempatkan diri secara berarti dan bermakna di tengah-tengah alam semesta ini. Manusia tidak mampu menjawab pertanyaan yang sangat mendasar dalam kehidupan tanpa agama, yaitu dari mana manusia datang, apa tujuan manusia hidup di dunia, dan mengapa manusia ada dan ke mana manusia kembalinya setelah mati.

\section{Fungsi agama dalam kehidupan masyarakat}

Agama tidak akan mungkin dapat dipisahkan dari kehidupan masyarakat, karena agama itu sendiri diperlukan dalam kehidupan masyarakat. Fungsi agama dalam masyarakat berdasarkan prakteknya, antara lain:

Falasifa, Vol. 9 Nomor 1 Maret 2018 | 103 
Mar'atus Sholihah

a. Berfungsi edukatif

Ajaran agama secara yuridis berfungsi menyeluruh dan melarang. Kedua unsur suruhan dan larangan ini mempunyai latar belakang mengarahkan bimbingan agar pribadi penganutnya menjadi baik dan terbiasa dengan yang baik menurut ajaran agama masing-masing.

b. Berfungsi penyelamat

Keselamatan yang meliputi bidang secara luas adalah keselamatan yang diajarkan oleh agama. Keselamatan yang diberikan oleh agama kepada penganutnya adalah keselamatan yang meliputi dua alam yaitu: dunia dan akhirat. Agama mengajarkan para penganutnya untuk mengenal terhadap sesuatu bersifat sakral yang disebut supranatural.

c. Berfungsi sebagai perdamaian

Seseorang yang bersalah atau berdosa dapat mencapai kedamaian batin melalui tuntutan agama. Rasa berdosa dan rasa bersalah akan segera menjadi hilang dari batinnya apabila seseorang yang bersalah telah menebus dosanya melalui taubat, pensucian jiwa, atau pun penebusan dosa.

d. Berfungsi sebagai sosial control

Ajaran agama oleh penganutnya dianggap sebagai norma-norma dalam kehidupan, sehingga dalam hal ini agama dapat berfungsi sebagai pengawas, baik secara individu maupun secara kelompok, karena:

1) Secara instansi, agama merupakan norma yang harus dipatuhi oleh para pengikutnya.

2) Secara dogmatis (ajaran) mempunyai fungsi kritis yang bersifat profetis (kenabian).

e. Berfungsi sebagai pemupuk rasa solidaritas

Para penganut agama secara psikologis akan merasa memiliki kesamaan dalam satu-kesatuan pada iman dan kepercayaan. Rasa kesatuan ini akan menimbulkan rasa solidaritas dalam kelompok maupun perorangan, bahkan kadang-kadang dapat membina rasa persaudaraan yang kokoh. Rasa persaudaraan (solidaritas) itu bahkan dapat mengalahkan rasa kebangsaan. ${ }^{5}$

\section{Sifat-sifat Agama Pada Anak}

Pembahasan sifat-sifat agama pada anak di usia jenjang pendidikan dasar memiliki beberapa kategori, diantaranya:

${ }^{5}$ H. Ramayulis, Psikologi Agama (Jakarta: Radar Jaya, 2007), hlm. 227-233.

104 | ҒaLASIFA, Vol. 9 Nomor 1 Maret 2018 
1. Unreflective (tidak mendalam)

Seorang anak akan melakukan komunikasi dengan tuhan ketika dia diceritakan bahwa tuhan itu bisa memberi kita sesuatu, tetapi ketika tidak diberikan dia tidak mau berdoa. Pemahan anak itu masih bersifat nyata atau logis pada intinya.

\section{Egosentris}

Munculnya egosentris yaitu anak memiliki rasa kagum kepada sesuatu yang dia lihat tersebut.

\section{Antbromotphis}

Anak beranggapan bahwa tuhan itu seperti manusia, melakukan, menghukum layaknya seperti manusia. Hasil penelitian yang dilakukan oleh Praff, pandangan anak terhadap tuhan adalah "tuhan mempunyai wajah seperti manusia, telinganya lebar dan besar. Tuhan tidak makan tapi hanya minum embun”. Konsep ke-tuhanan yang demikian itu mereka bentuk sendiri berdasarkan fantasi masing-masing.

\section{Verbalis dan ritualis}

Kehidupan anak sebenarnya tumbuh secara alami, mereka mulai menghafal secara baik dari sifat tuhan itu, tetapi ini tidak membawa anak kepada perkembangan agama anak selanjutnya. Ketekunan anak dalam beragama sangat berpengaruh ketika dewasa, karena sesuatu itu sudah dia lakukan, sehingga menjadi terbiasa dalam melakukan ibadah maupun yang bersifat ritual.

\section{Imitative}

Lingkungan anak sangat berpengaruh terhadap perkembangan keagamaannya, perkembangan agama anak secara imitative dia dapatkan dengan meniru, baik dalam bentuk berdo'a, beribadah, dan lain sebagainya. Lingkungan anak sangat menentukan akan keagamaan anak itu.

\section{Rasa heran}

Rasa heran dan kagum merupakan tanda dan sifat keagamaan yang terakhir pada anak. Rasa kagum yang ada pada orang dewasa berbeda dengan rasa kagum pada anak yang belum bersifat kritis dan kreatif. Mereka hanya kagum terhadap keindahan lahiriah saja. Hal ini merupakan langkah pertama dari pernyataan kebutuhan anak akan dorongan untuk mengenal sesuatu yang baru (new experience). Rasa kagum mereka dapat disalurkan melalui ceritacerita yang menimbulkan rasa takjub. ${ }^{6}$

\footnotetext{
${ }^{6}$ H. Jalaluddin, Psikologi Agama ..., hlm.70-74.
} 
Mar'atus Sholihah

\section{Perkembangan Jiwa Keagamaan Pada Anak}

Kemampuan seseorang untuk mengenali atau memahami nilai agama yang terletak pada nilai-nilai luhurnya serta menjadikan nilai-nilai dalam bersikap dan bertingkah laku merupakan ciri dari kematanan beragama, jadi kematangan beragama terlihat dari kemampuan seseorang untuk memahami, menghayati serta mengaplikasikan nilai-nilai luhur agama yang dianutnya dalam kehidupan seharihari. Ia menganut suatu agama karena menurut keyakinannya agama tersebutlah yang terbaik, karena itu ia berusaha menjadi penganut yang baik, keyakinan itu ditampilkannya dalam sikap dan tingkah laku keagamaan yang mencerminkan ketaatan terhadap agamanya.

Perkembangan yang dicapai oleh kebanyakan anak-anak, maka kedewasaan jasmani belum tentu berkembang setara dengan perkembangan rohaninya, sehingga seringkali terjadi ketika usia anak sudah semakin bertambah (secara biologis) namun belum tentu bertambah juga kematangan pribadinya. Orang yang sudah dewasa secara normal maka ia akan memiliki pula kematangan rohaninya, seperti kematangan berpikir, kematangan kepribadian maupun kematangan emosinya. Perimbangan antara kematangan jasmani dan kematangan rohani ini adakalanya tidak berjalan sejajar. ${ }^{7}$

Keterlambatan pencapaian kematangan rohani ini menurut ahli psikologi pendidikan sebagai keterlambatan dalam perkembangan kepribadian. Faktorfaktor ini menurut Dr. Singgih D. Gunarasa dapat dibagi menjadi dua kelompok, yaitu faktor yang teridiri dalam diri anak dan faktor yang berasal dari lingkungan tempat ia tinggal atau bermain. Faktor-faktor intern anak itu dapat mempengarunhi perkembangan kepribadian adalah konstitusi tubuh, struktur dan keadaan fisik, koordinasi motorik, kemampuan mental dan bakat khusus, inteligensi tinggi, hambatan mental, dan bakat khusus serta emosionalitas. Factorfaktor tersebut dapat mempengaruhi proses perkembangan kepribadian dalam diri seorang anak. Faktor lingkungan adalah faktor keluarga dan sekolah. Faktor-faktor lain yang juga mempengaruhi perkembangan kepribadian seseorang adalah berasal dari faktor kebudayaan. Faktor kebudayaan tempat seseorang itu dibesarkan. Faktor kebudayaan akan mempengaruhi atau membentuk tingkah laku dan kepribadian seseorang.

7 Jalaludin, Psikologi Agama: Memahami Perilaku Keagamaan Dengan Mengaplikasikan Prinsip-Prinsip Psikologi..., hlm. 124.

$106 \mid$ FaLASIFA, Vol. 9 Nomor 1 Maret 2018 


\section{Teori Tentang Sumber Kejiwaan Agama}

\section{a. Teori monistik $($ mono $=$ satu $)$}

Teori monistik berpendapat bahwa yang menjadi sumber kejiwaan agama adalah satu sumber kejiwaan, selanjutnya sumber tunggal manakah yang dimaksud paling dominan sebagai sumber kejiwaan itu? Timbul beberapa pendapat yang dikemukakan oleh:

1) Thomas Van Aquino; dia mengemukakan bahwa yang menjadi sumber kejiwaan agama itu ialah berpikir. Manusia bertuhan karena manusia menggunakan kemampuan berpikirnya.

2) Fredrick Hegel; dia mengatakan agama adalah suatu pengetahuan yang sungguh-sungguh benar dan tempat kebenaran abadi adalah berdasarkan hal itu, agama semata-mata merupakan hal-hal atau persoalan yang berhubungan dengan pikiran.

b. Teori fakulti (faculty theory)

Teori ini berpendapat bahwa tingkah laku manusia itu tidak bersumber pada suatu faktor yang tanggap, tetapi terdiri dari atas beberapa unsur antara lain yang dianggap memegang peranan penting adalah fungsi cipta (reason), rasa (emotion) dan karsa (will).

1) Cipta (reason)

Cipta merupakan fungsi intelektual jiwa manusia. Ilmu kalam (teologi) adalah cerminan adanya pengaruh fungsi intelek ini. Perasaan intelek ini dalam agama merupakan suatu kenyataan yang dapat dilihat, terlebih-lebih dalam agama modern, peranan dan fungsi reason ini sangat menentukan.

2) Rasa (emotion)

Fungsi reason berperan dalam pemikiran mengenai supranatural saja, sedangkan untuk memberi makna dalam kehidupan beragama diperlukan penghayatan yang seksama dan mendalam sehingga ajaran ini tampak hidup.

3) Karsa (will)

Will berfungsi mendorong timbulnya pelaksanaan doktrin serta ajaran agama berdasarkan fungsi kejiwaan.

Fungsi ketiganya yaitu:

1) Cipta (reason) berperan untuk menentukan benar atau tidaknya ajaran suatu agama berdasarkan pertimbangan intelektual seseorang.

2) Rasa (emotion) menimbulkan sikap batin yang seimbang dan positif dalam menghayati kebenaran ajaran agama.

FaLASIFA, Vol. 9 Nomor 1 Maret $2018 \mid 107$ 
Mar'atus Sholihah

3) Karsa (will) menimbulkan amalan-amalan atau doktrin keagamaan yang benar dan logis. ${ }^{8}$

Tahapan-tahapan Perkembangan Agama Pada Masa Anak-anak

Masa anak-anak dimaksudkan masa sebelum masa remaja yaitu sebelum umur + 12 tahun, di mana masa tersebut sebenarnya mengandung tida periodesasi perkembangan yaitu:

1. Umur $0.0-2.0$ tahun disebut masa vital.

2. Umur 2.0 - 6.0 disebut masa kanak-kanak.

3. Umur 6.0 - 12 tahun disebut masa sekolah.

Masa vital adalah masa di mana anak banyak membutuhkan pertolongan dari orang di sekitarnya dalam hal ini adalah orang tuanya. Usaha orang tua dalam memberikan pertolongan dan perlindungan kepada anak pada masa tersebut akan mempunyai pengaruh yang sangat besar sekali terhadap pertumbuhan fisik dan perkembangan psikis anak serta dalam pembentukan pribadi anak.

Masa kanak-kanak merupakan perkembangan psikis yang terbesar. Masa ini oleh Kohnstamn dinamakan masa estetis di mana anak mengalami perkembangan pengamatan indera yang terbesar. Masa ini anak mulai sadar akan akunya dan mulai mengenal antara dirinya dengan orang lain. Masa ini juga oleh orang barat biasanya disembut dengan masa Trotz atau disebut juga dengan individualisme yang pertama, yaitu suatu masa di mana anak menunjukkan kecenderungan untuk berkeras kepala, suka menolak perintah atau saran-saran dari orang lain.

Masa sekolah yaitu di mana anak sudah mulai dianggap matang untuk mengikuti pelajaran di sekolah dasar, kalau anak tersebut perkembangannya normal. Tanda-tanda kematangan itu antara lain:

1. Kesadaran terhadap kewajiban, pekerjaan, dan berkesanggupan untuk menjalankan tugas-tugas yang diberikan oleh orang lain kepadanya, walaupun sebenarnya dia tidak menyukainya.

2. Perasaan sosial kemasyarakatan sudah mulai tumbuh dan berkembang, di mana hal ini dapat terlihat di dalam pergaulan anak dengan teman-temannya dan saling bekerja sama.

3. Perkembangan jasmani yang cukup kuat dalam melaksanakan kewajiban dan tugas-tugas yang diberikan kepadanya.

4. Anak sudah cukup memiliki perkembangan intelek yang cukup besar, hingga memiliki minat, kecakapan dan pengetahuan. ${ }^{9}$

${ }^{8}$ Ibid..., hlm.54-58.

108 | ҒaLASIFA, Vol. 9 Nomor 1 Maret 2018 
Teori-teori tentang timbulnya jiwa keagamaan pada anak, yaitu: ${ }^{10}$

1. Rasa ketergantungan (sense of depende)

Teori ini dikemukakan oleh Thomas melalui teori four wishes. Teori yang menjelaskan, manusia dilahirkan kedunia memiliki empat kebutuhan, yaitu untuk perlindungan, keinginan akan pengalaman yang baru, keinginan untuk mendapat tanggapan, dan keinginan untuk dikenal. Penglaman-pengalaman yang dilaluinya menimbulkan jiwa keagamaan pada diri anak.

2. Insting keagamaan

Menurut Woodwort, bayi yang dilahirkan sudah memiliki insting diantaranya insting keagamaan. Tindak keagamaan pada diri seorang anak belum terlihat karena fungsi kejiwaanya belum berfungsi secara sempurna, maka pembelajaran agama perlu diajarkan kepada anak sedini mungkin. Potensi keagamaan tersebut baru akan berfungsi secara sempurna ketika seorang anak telah mampu bersosial dan berkomunikasi.

Penelitian Ernest Harms tentang perkembangan agama pada anak-anak itu melalui beberapa fase. Bukunya The Development Of Religious On Children, ia mengatakan bahwa perkembangan agama pada anak-anak itu melalui tiga tingkatan, yaitu: ${ }^{11}$

1. The Fairy Tale Stage (tingkat dongeng)

Tingkatan ini dimulai pada umur 3-6 tahun. Tingkat ini menjelaskan konsep mengenai Tuhan lebih banyak dipengaruhi oleh emosi dan fantasi. Tingkat perkembangan ini menunjukkan bahwa anak menghayati konsep Tuhan sesuai dengan tingkat perkembangan intelektualnya. Kehidupan masa ini masih banyak dipengaruhi oleh dunia fantasinya, sehingga dalam menanggapi keagamaan pun anak masih menggunakan konsep fantasinya yang bisa berupa dongeng-dongeng yang kurang masuk akal.

2. The Realistic Stage (tingkat kenyataan)

Tingakatan ini dimulai pada umur 7-12 tahun. Tingakatan ini dimulai ketika anak memasuki masa sekolah. Masa-masa ini konsep ke-Tuhanan anak sudah mencerminkan konsep-konsep yang berdasarkan kepada kenyataan. Konsepkonsep ini timbul melalui lembaga-lembaga keagamaan dan pengajaran agamanya. Masa usia ini anak-anak lebih tertarik kepada lembaga-lembaga

\footnotetext{
${ }^{9}$ M. Hafi Anshari, Dasar-dasar Ilmu Jiwa Agama..., hlm.68-70.

${ }^{10}$ Mansur, Pendidikan Anak Usia Dini dalam Islam (Yogyakarta: Pustaka Pelajar, 2009), hlm. 47.

${ }^{11}$ Beit-Hallahmi, B dan Arggyl, M, The Psychology Of Religious Behawiour, Belief And Experience (London and New York: Routledge, 1997), hlm. 147.
}

Falasifa, Vol. 9 Nomor 1 Maret 2018 | 109 


\section{Mar'atus Sholihah}

agama atau pembelajaran agama yang kemudian ia ikuti dan dipelajari dengan penuh minat.

3. The Individual Stage (tingkat individu)

Tingkatan ini mulai pada umur $12+$ tahun. Anak sudah memiliki tingkat emosi yang paling tinggi sejalan dangan umurnya, ketika seorang anak sudah dapat membedakan dan menetukan keyakinan dirinya.

Zakiah Daradjat menuturkan, perkembangan agama pada anak sangat ditentukan oleh pendidikan dan pengalaman yang dilaluinya, terutama pada masamasa pertumbuhan yang pertama (masa anak) dari umur 0-12 tahun. Seorang anak yang pada masa anak itu tidak mendapatkan didikan agama dan tidak pula mempunyai pengalaman keagamaan, maka ia nanti setelah dewasa akan cenderung bersifat negatif terhadap agama. ${ }^{12}$ Agama masuk kedalam diri anak bersama pertumbuhan pribadinya yaitu sejak lahir, bahkan ketika dia masih dalam kandungan, karena dalam pengamatan ahli jiwa orang-orang yang mengalami kesukaran kejiwaan tampak bahwa keadaan dan sikap orang tua ketika si anak dalam kandungan telah mempunyai pengaruh terhadap pertumbuhan jiwa si anak dikemudian hari.

\section{Metode Keteladanan Sebagai Solusi Inti}

Anak mulai mengenal tuhan melalui orang tua dan lingkungannya. Katakata, sikap, tindakan, dan perbuatan orang tua sangat memepengaruhi perkembangan agama pada anak. Anak menerima apa saja yang dikatakan oleh orang tuanya kepada anaknya. Seorang anak belum mempunyai kemampuan untuk memikirkan kata-kata misalnya, Allah. Si anak berpikir, orang tuanya adalah benar, berkuasa, pandai, dan menentukan. Hubungan anak dengan orang tua sangat berpengaruh terhadap perkembnagn agama pada anak. Hubungan yang kurang serasi antara anak dan orang tua akan menyebabkan sukarnya perkembangan agama pada anak, oleh karena itu guru agama di SD/ MI terutama kelas 1 dan 2 menghadapi tugas yang tidak ringan dalam menghadapi perkembangan agama pada anak. Guru agama hendaknya mendekatkan ajaran agama itu dalam kehidupan anak sehari-hari. Guru harus menampakkan sikap kasih sayang dan melatih anak untuk saling menyayangi satu sama lain, di samping itulah letak pentingnya pembiasaan-pembiasaan dalam pendidikan agama pada khususnya.

${ }^{12}$ Zakiah Daradjat, Ilmu Jiwa Agama (Jakarta: Bulan Bintang, 1976), hlm. 74.

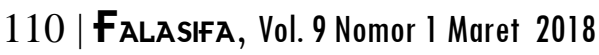




\section{Pembiasaan pendidikan agama pada anak}

Pembinaan pada anak agar mempunyai sifat terpuji perlu membiasakannya untuk melakukan yang baik yang diharapkan nanti anak tersebut akan mempunyai sifat-sifat itu dan menjauhi sifat tercela. Kebiasaan dan latihan itulah yang membuat anak tersebut cenderung kepada melakukan yang baik dan meninggalkan yang kurang baik, semakin kecil umur si anak, hendaknya semakin banyak latihan dan pembiasan agama yang dilakukan kepada anak. Anak bertambah umur, hendaknya semakin bertambah pula penjelasan dan pengertian tentang agama itu diberikan sesuia dengan perkembangan kecerdasannya.

Guru agama harus menyadari bahwa anak adalah dalam arti keseluruhannya, baik tubuh (jasmani), pikiran dan perasaannya. Seorang anak bukan orang dewasa yang kecil, artinya bukan hanya tubuh dan kemampuan jasmaninya saja yang kecil tapi juga kecerdasan, persaaan dan keadaan rohaninya juga berlainan dengan orang dewasa. Kepercayaan anak kepada tuhan dan agama pada umumnya bertumbuh melalui latihan sejak kecil. Pembiasaan dan pendidikan agama itu didapatnya dari orang tua dan gurunya terutama guru agama.

Pembiasaan dalam pendidikan anak sangat penting, terutama dalam pembentukan pribadi, akhlak dan agama. Pembiasaan-pembiasaan agama itu akan memasukkan unsur-unsur positif dalam pribadi anak yang sedang tumbuh, semakin banyak pengalaman agama yang didapatnya melalui pembiasaan itu, akan semakin banyaklah unsur agama dalam pribadinya dan semakin mudah ia memahami ajaran agama.

\section{Hal yang perlu diperhatikan oleh guru}

Setiap guru jangan lupa bahwa ia adalah unsur terpenting dalam sekolah. Guru yang pandai, bijaksana, dan mempunyai keikhlasan dan sikap positif terhadap pekerjaannya akan dapat membimbing anak-anak didik ke arah yang positif yang diperlukan dalam hidupnya dikemudian hari. Guru juga tidak boleh lupa bahwa anak datang ke sekolah untuk belajar, belum tentu atas kemauannya sendiri, barangkali karena hanya memenuhi keinginan orang tuannya. Guru yang menyadari hal-hal itu ia akan berusaha memperbaiki sikap jiwanya terhadap tugas yang telah dipilihnya dan meningkatkan kemampuannya untuk dapat melaksanakan tugas sebaik-baiknya. Ia juga harus meningkatkan pengetahuannya tentang berbagai ilmu yang diperlukan dalam tugasnya, agar ia dapat membuat anak yang enggan atau tidak senang terhadap pelajarannya. Upaya peningkatan kesadaran dan keikhlasan terhadap pekerjaan serta peningkatan pengetahuan dan keterampilan untuk 


\section{Mar'atus Sholihah}

melaksanakan tugas sebagai pendidik guna membina hari depan anak dan generasi muda pada umumnya, maka guru akan dapat membimbing kearah pembinaan hari depan yang baik.

Sikap-sikap guru agama yang seharusnya menurut Zakiyah Daradjat adalah:

a. Guru agama adalah pembina pribadi, sikap dan pandangan hidup anak, karena itu setiap guru agama harus berusaha membekali dirinya dengan segala persyaratan sebagai guru, pendidik, dan pembentuk kepribadian anak untuk masa depan anak.

b. Guru agama harus memahami betul perkembangan jiwa anak agar dapat mendidik anak dengan cara yang cocok dan sesuia dengan umur anak.

c. Pendidikan agama pada umur SD/ MI harus lebih banyak percontohan dan pembiasaan.

d. Guru harus memahami latar belakang anak yang menimbulkan sikap tertentu pada anak. ${ }^{13}$

\section{KESIMPULAN}

Keseimbangan kematangan beragama pada seseorang ditentukan oleh faktor jasmani dan rohani, begitu pun pada anak. Keseimbangan kematangan ini mampu tercapai apabila si anak memiliki dukungan perkembangan dari keluarga, lingkungan dan budaya. Faktor terpenting dalam perkembangan kematangan adalah faktor internal, di mana kematangan anak tersebut berasal dari dalam dirinya. Perkembangan kematangan beragama anak berdasarkan beberapa teori psikologi agama dan psikologi anak dimulai dari usia 0 tahun dan diakhiri pada usia +12 tahun dengan bebebrapa fase dan tingkatan yang dilalui. Peran keluarga dan guru sebagai keluarga di luar rumah menjadi sangat penting pada proses perkembangan kematangan beragama anak, karena peran tersebut menjadi penentu ke depan bagi baik-buruknya akhlak dan keberagamaan anak.

\section{DAFTAR PUSTAKA}

Anshari, Hafi. Dasar-Dasar Ilmu Jiwa Agama, Surabaya: Usaha Nasional, 1991.

Beit-Hallahmi, B dan Arggyl, M. The Psychology Of Religious Behaviour, Belief And Experience. London and New York: Routledge, 1997.

Daradjat, Zakiah. Ilmu Jiwa Agama, Jakarta: Bulan Bintang, 1976.

Jalaludin. Psikologi Agama; Memahami Perilaku Keagamaan Dengan Mengaplikasikan Prinsip-Prinsip Psikologi, Jakarta: PT Raja Grafindo Persada. 2010.

${ }^{13}$ Zakiah Daradjat, Ilmu Jiwa Agama ..., hlm. 75.

112 | FalASIFA, Vol. 9 Nomor 1 Maret 2018 
Kedewasaan Beragama pada Anak Usia Dasar

- Psikologi Agama; Memahami Perilaku Keagamaan Dengan Mengaplikasikan Prinsip-Prinsip Psikologi, Jakarta: PT Raja Grafindo Persada. 2012.

Mansur. Pendidikan Anak Usia Dini Dalam Islam, Yogyakarta: Pustaka Pelajar, 2007.

Ramayulis. Psikologi Agama, Jakarta: Radar Jaya, 2007.

Ismail, Roni. Konsep Toleransi Dalam Psikologi Agama, Jurnal Religi, Vol. VIII, No. 1, Januari 2012. 
Mar'atus Sholihah

114 | ҒaLASIFA, Vol. 9 Nomor 1 Maret 2018 